\title{
The Reception of Kadazandusun University Students towards the Kadazandusun Columns in Sabah's Local Newspapers
}

\author{
Andreas Totu and HalinaSenderaMohd Yakin \\ Centre for the Promotion of Knowledge and Language Learning Universiti Malaysia Sabah
}

\begin{abstract}
This paper aims at investigating the motivations that generate the interests of Kadazandusun students to read news from the Kadazandusun column in three local newspapers namely the Daily Express, The New Sabah Times and Borneo Post. This study also examines the newspaper reading habits among university students and explores what elements in the news that is able to gratify their reading needs. There are 140 respondents for this study that consist of students from Universiti Malaysia Sabah. The Uses and Gratifications Theory is used to explain the reading patterns among the respondents. Preliminary outcomes show that Kadazandusun students appear not interested to read the Kadazandusun language news because they are no longer proficient with the language and news that published in the column are available in the English and Malay versions. Respondents only visit the column to look for specific Kadazandusun terms or words. Some recommendations are put forward to improve the column in this study.
\end{abstract}

Keywords: Kadazandusun columns, reading habits, Uses and Gratification Theory, Sabah, Malaysia

\section{Sabah Newspapers in Brief}

According to the brief background information on newspaper in Sabah, produced by the Sabah State Achieve (1994), the oldest and first English pre-war newspaper in Sabah was the Herald which was printed at Kudat in 1883 and at Sandakan in 1885. It ceased to continue in 1946 after the World War II. The first post-war English newspaper was the North Borneo News which was published in 1949. In 1951, the Kinabalu News Bulletin, the second English newspaper was published by the Amateur Athletic Association of North Borneo. Two years later, the name North Borneo News was changed to The Sabah Times and in 1969, the newspaper was renamed The Kinabalu Sabah Times. However, it was again renamed The Sabah Times until today.

The third English newspaper in Sabah was the Anak Sabah. This newspaper was launched in 1956 in Jesselton (now Kota Kinabalu) meant for children.The Daily Express, the sister newspaper of the Overseas Chinese Daily News, was published on 1 March, 1963.The Kinabalu Sunday Times was a weekly newspaper published and printed in English and Malay languages in 1965. In 1966, its sister newspaper - The Kinabalu Times - was published, also in bilingual.In 1976, the Kinabalu Weekend was published and printed in Kota Kinabalu. This newspaper used both English and Chinese languages. Twelve years later the next English newspaper named the Borneo Mail - the first tabloid newspaper - was printed. This newspaper was published by the Nountun Press Sdn. Bhd. In three languages - English, Malay and Kadazan. However, it ceased operation in 1990. The Borneo Post, another English newspaper started its publication in 1994. This newspaper is a subsidiary of See Hua Reality (Sabah) Sdn. Bhd. The Utusan Borneo, a sixteen page tabloid in Malay language was also published to supplement the Borneo Post.

Besides English newspapers, Chinese newspapers were alsoprominent after the WWII. The Overseas Chinese Daily News was published in 1949 in handwritten form. This is also the oldest Chinese newspaper in Sabah. The Sandakan JihPaois the oldest newspaper in Sandakan which was published in 1960. Several other Chinese newspapers were issued during that decade namely Kinabalu Observer (Evening Post), Api Siang Pao, Eastern Malaysia Evening Post, Kinabalu Daily News, Merdeka Daily News and the Borneo Times. On 7 August, 1976, the Asia Times was issued followed by the Sabah Shi Pao in the 1980s. The Today News was published during the same decade but ceased operation in 1990 (Sabah State Achieve, 1994).

All newspapers production after the Herald was handled by business communities. Since most businesses after World War II were controlled by the Chinese community, the development of newspapers in Sabah was also very closely related to the Chinese community. As a result, many newspapers during that time were either in English or Chinese. Besides, the demand for newspaper was determined by the literacy rate. Between 1946 to 1956, the number of students in mission and Chinese schools was higher than those in government schools. For example in 1956, there were 12,479 and 10,867 pupils studying in the Chinese and Mission schools respectively as compared to only 6,905 in the government schools (Sansalu, 2008). According to the North Borneo Annual Report $(1949: 35 ; 1950: 31)$ the number of Chinese attending school was greater than the Kadazan, Dusun and Murut (in Sansalu, 2008: 172). Therefore, only a handful of indigenous people were able to read newspaper at that time. The people from the districts of Penampang and Papar had better 
opportunity to receive formal education (government or mission schools) because of its proximity to urban development; hence they have better reading skills (Glyn-Jones, 1953 in Sansalu, 2008). This scenario may have affected the development of print media in Sabah, Malaysia.

\section{The Kadazandusun Columns}

News in the Kadazanlanguage was first published on 28 April 1955 in The Sabah Times newspaper. It was called the Kadazan Corner slotted in the Malay section. The news consisted of short stories about travel, food and social activities. For instance, 'OhunokHindungDoidPapar' (Papar's Eels are Delicious) or 'Notipu O Toigi do Hazag' (Sailboat Mast was Broken). Some are letters to the editors. Apparently, the first kadazan dialect used was KadazanPapar. The KadazanPenampang dialect started only on the 14 June 1955, meanwhile the Dusunlanguage started on 6 August 1955. Some news in Lotud dialect was also observed during this period. On 15 May 1956, the first Kadazan supplement was printed which was published once in two weeks. This is a full page news in the Kadazan language. It was later printed daily until today.

The Daily Express started its Kadazan column in 1975, which was called PangaanKadazan or Kadazan Column. Apart from publishing political, socio-economic news, it also published poems. The later newspapers such as the Borneo Mail and Borneo Post also have their own Kadazandusun columns that were published daily.

\section{Youths and Newspaper Reading Habits}

Reading is one of the most important components in learning language (Pandian, 1997; Mokatsi, 2005) and it would also develop a good writing skill, increase vocabulary and grammar(Krashen, 1993). An improvement of language proficiency makes the reader to be a better speaker.Therefore, it is imperative for anyone, especially for university and college students, to have a positive reading habit because they will be the potential future leaders of a country. However, previous research (Kaur and Thiyagarajah, 1999; Pandian, 1997; Frank Small \& Associates, 1996 and Subashini\&Balakrishnan, 2012) seemed to show that university and college students in Malaysia have lack of reading habits and this phenomenon becomes a concern to educators and government alike.

The study by Kaur \&Thiyagarajah (1999) showed that Malaysian students read very little. Their preferences on technological gadgets and television were higher compared to reading books or newspapers. Such research outcomes were also shared by the results of the study conducted by Pandian (1997) and Frank Small\& Associates(1996). A recent study conducted among 119 polytechnic students from Engineering and Business department in the selected Polytechnic in 2012 by Subashini and Balakrishnan, also revealed that; (i) the polytechnics students have low interest in reading; (ii) students do not enjoy reading as much as they enjoy doing other technology related activities.

However, contradictory outcomes were found in a study conducted by Nor Shahrizaand Amelia (2007). Their study outcomes showed that youths are still interested to read during their leisure time. Their 127 samples were students at the International Islamic University Malaysia. Her study found out that $61 \%$ ( 76 respondents) of the respondents read during their leisure time and out of this number, $80 \%$ (63 respondents) chose newspaper as their reading material. Apparently, magazine was the most read material during their leisure time. The outcome of this study was surprising because the general notion shows that Malaysians are generally uninterested in reading during their leisure time. They were only read, such as academic books, because they have to (Kaur and Thiyagarajah, 1999; Pandian, 2000).

It was claimed that the number of young people who read newspaper is dwindling tremendously. The National Literacy Surveys carried out in 1996 and 2005 by the National Library both concluded that Malaysians on average read only two books per year, as opposed to the Japanese and French, who each read 10 books a year. Leading the pack were the Americans and the Canadians, who each read an average of 17 books a year.It is great malaise that Malaysians are less affluent readers. Intertwined with hedonism, audio-visual and digitalbased entertainment, youth and adults alike no longer find pleasure in reading as a pastime or source of entertainment (cited from AnasAlamFaizli, 2012).

This phenomenon can also be assumed to happen among the Kadazandusun youths. Previous research outcomes show that the lack of reading interest among youths was caused by several factors. One of the factors is time constraint. Malaysians nowadays spend most their time in pursuit of economic and wealth possessions due to the rising cost of living. Secondly, the price of books soars as inflation increases. Malaysians appear incapable to buy exorbitant prices of books making them to reprioritise their spending. Thirdly, youths now merely lack of interest to read because of the increasing popularity of more attractive and interactive media forms such as Internet, mobile phone and new technological gadgets (Liu, 2005; Pandian, 2010).

Why youths appear uninterested to read is of concern that requires assessments and evaluations. If the scenario portrays the general interest of reading all genres of reading material and languages, then what about reading a particular genre and language. Therefore, a research was conducted to answer this concern. This study attempts to prove the following hypotheses. 
H1: Kadazandusun youths are not interested to read newspaper.

H2: Kadazandusun youths are not interested to read news from the Kadazandusun column.

H3: Kadazandusun youths do not read news in the Kadazandusun column because it does not provide gratification to young readers.

The objectives of this paper are as follows:

(a) To find out the newspaper reading habits among the Kadazandusun youths;

(b) To identify the interests of the Kadazandusun youths towards the Kadazandusun columns in Sabah's local newspapers; and

(c) To determine the factors contributing to their interests towards the Kadazandusun column.

Previous literatures (Katz et al. (eds), 1974;McQuail\&Windahl, 1981: Chandler \&Munday, 2011) indicated that the relationships between the reasons to use media and the gratifications sought from the involvement of media seemed able to explain user's choice. Therefore, the Uses and Gratification Theory was used to determine the Kadazandusunyouths' interests on newspaper, particularly the Kadazandusun columns in Sabah's local newspapers.

\section{The Uses and Gratifications Framework}

The Uses and Gratifications Theory (U\&G)is a functionalist approach that examines why people use media (Chandler \&Munday, 2011). Essentially, Uses and Gratificationstheory proposes that audience's use of media is motivated towards gratifying certain needs. This theory started from the 1940s, when Herzog explored, among other problems, the gratifications sought and obtained by (soap opera) audience in 1944. Nevertheless, the work of Katz et al. (eds) (1974) and McQuail\&Windahl (1981) appeared to be more popular because of their focus on audience-media relations. Audience is seen as an active individual who is actively seeking combinations of gratifications from the range of media output selected and 'used' (O'Sullivan et al., 1994).

The U\&G theory initiated a paradigm shift about audience research from a traditional passive and static hypodermic view of media-audience effects to a more dynamic and active view. It proposes the idea of 'what do people do with the media', which is extremely in opposition to a previous general thinking about media effects of 'what does media do to people'. This theory has been developing ever since especially in terms of the number and types of variables and typologies due to the development of mass media and the use of U\&G theory in cross-disciplinary studies.

Most of the studies using U\&G theory during the 1970s and 1980s were focused on studying why people use television. The four typologies introduced by McQuail et al. (1972) have been added and/or modified by various researchers such as Palmgreen\& Rayburn (1979), Blumer (1979), Rubin (1983), Ostman\& Jeffers (1980) and Bantz (1982). The U\&G theory was also claimed to be the first theoretical framework employed to research on new media in the 1990s, such as Internet, VCR and computer (Morris \&Ogan, 1996; Ferguson \&Perse, 2000). However, the use of the U\&G theory in studying print media, particularly newspapers is still relevant.

The four typologies of media-audience interactions introduced by McQuail et al. (1972) are important to be understood to study how media provides gratification to audiences. They are as follows:

(1) Surveillance - The media provide materials which gratify the need for information about the immediate and more distant social world: information about issues and events that directly and indirectly influence the individual's life, including information to assist students in their studies.Nevertheless, for young readers, they would be gratified for news contents that are able to cater their needs. According to Barnhurst and Wartella (1991), young readers seemed uninterested to news that are closely acquainted to 'adult affairs' such as politics and economics.

(2) Personal Identity -Media contents may be used symbolically to explore, challenge, adjust, or confirm the individual's sense of identity and self. The media provide ways to 'assess' and 'locate' themselves, and hence to respond to problems of personal identity management, which includes the comparison of oneself, one's sense of situation, sets of values and outlooks.Eighmey and McCord (1995) quoted the survey conducted by World Wide Web (Web) that respondents are most attracted to information formats that speak to them in a more personalized voice and in a broader entertaining context (cited from Ruggiero, 2000). This indicates the tendency of youths to choose information that supports or enhances their identities.

(3) Diversion - The media provide material which is used by people to 'escape' or be diverted from routines - for example, work routines, and a wide variety of problems that confront and constrain them. In so 
doing, the media provide important emotional release and relaxation from these and other constraints, albeit temporarily. This is normally done through gratifying themselves with various modes of entertainment.Escaping stressful day can also be done through immersing themselves with 'entertaining' activities such as doing things that produce enjoyment to themselves, especially to those who have a positive interest in reading. According to an unpublished $\mathrm{PhD}$ thesis of Clyde H. Bentley (2000), entertainment-related items such ascomics and crosswords were of greater interest to those with high levels of reading habit, but classified advertising was of lower reading interest respondents. However, such enjoyment and entertainment can best be obtained from various new media forms particularly the Internet and social media because of the element of interactivity. Interactivity does not simply mean users are able to choose a wide array of merchandise they like from the Internet or using multimedia video or obtaining information on demand, but its scope is wider which covers a multifaceted human communication and representation.

Ha and James (1998) cited five dimensions of interactivity: playfulness, choice, connectedness, information collection and reciprocal communication. Ha and James suggested that for 'self-indulgers' and 'web-surfers', playfulness and choice dimensions of interactivity fulfil self-communication and entertainment needs. For task-oriented users, the connectedness dimension fulfils information needs.

(4) Personal Relationships - Media provide materials that gratify the need for companionship and sociability. They do this in two ways. Firstly, when we are alone we may use the radio and television to 'keep us company'; we may come to 'know' media personalities and characters as if they were personal friends. Secondly, knowledge and consumption of media programmes and output may often facilitate or serve as a focus for interaction with others.For expressive users, according to Ha and James (1998), the information collection and reciprocal communication dimensions allow them to initiate communication with others of common online interests.

\section{Research Methodology}

This study is a descriptive study in which the sample was selected through random sampling. The data were collected using a survey method and analysed through Statistical Packages of the Social Sciences (SPSS version 21). A total of 140 respondents took part in this study. They were students from Universiti Malaysia Sabah in Kota Kinabalu, Sabah, Malaysia from the Kadazandusun ethnic group. The instrument items were tested for their validity and reliability. The instrument has good level of validity shown from the obtained loading Eign value of more than 0.3. Meanwhile, the test of reliability using Cronbach's Alpha Co-efficient achieved 0.845 , which reflects a high level of reliability of the questionnaires.

\section{Analysis and Discussions}

This section presents the demographic data of the study that include gender, age, ethnic groups and place of stay. It also attempts to address the three hypotheses of this study, which are to prove that (1) Kadazandusun youths are not interested to read newspaper; (2) Kadazandusun are not interested to read news from the Kadazandusun columns; and (3) Kadazandusun youths do not read Kadazandusun news because they do not provide gratification to young readers.

\section{Demographic Background}

The total number of respondent for this study is 140 , consisted of students from various schools in Universiti Malaysia Sabah. They all come from various sub-ethnic groupsof the Kadazandusun tribe.

Table 1:Demographic Background

\begin{tabular}{|c|c|c|c|}
\hline Variable & Category & Frequency & Percentage \\
\hline \multirow[t]{2}{*}{ Gender } & Male & 63 & 45.0 \\
\hline & Female & 77 & 55.0 \\
\hline \multirow{5}{*}{ Age } & 19 years old & 11 & 7.9 \\
\hline & 20 years old & 56 & 40.0 \\
\hline & 21 years old & 36 & 25.7 \\
\hline & 22 years old & 14 & 10.0 \\
\hline & 23 and above & 23 & 16.4 \\
\hline \multirow{7}{*}{ Ethnic Groups } & Tangara & 12 & 8.6 \\
\hline & Dusun & 93 & 66.4 \\
\hline & Sino Kadazan/Dusun & 24 & 17.1 \\
\hline & Murut & 1 & 0.7 \\
\hline & Lundayeh & 3 & 2.1 \\
\hline & Tatana & 3 & 2.1 \\
\hline & Rungus & 4 & 2.9 \\
\hline Place of stay & Urban & 19 & 13.6 \\
\hline
\end{tabular}


The Reception of Kadazandusun University Students towards the Kadazandusun Columns in......

\begin{tabular}{|c|l|c|c|}
\hline \multicolumn{1}{|c|}{ Rural } & \multicolumn{1}{c|}{121} & \multicolumn{1}{c|}{ Table 2:Language Proficiency and Usage } \\
\hline \multicolumn{1}{|c|}{ Item } & \multicolumn{1}{|c|}{ Frequency } & Percentage \\
\hline \multirow{4}{*}{ Variable } & \multicolumn{1}{|c|}{ Language Proficiency } & 11 & 7.9 \\
\cline { 2 - 4 } & Extremely not fluent & 15 & 10.7 \\
\cline { 2 - 4 } & Not fluent & 53 & 37.9 \\
\cline { 2 - 4 } & Less fluent & 46 & 32.9 \\
\cline { 2 - 4 } & Fluent & 15 & 10.7 \\
\cline { 2 - 4 } & Very fluent & 78 & 55.7 \\
\cline { 2 - 4 } & Malay language & 2 & 1.4 \\
\cline { 2 - 4 } & English language & 23 & 16 \\
\cline { 2 - 4 } & Kadazandusun language & 34 & 24.3 \\
\cline { 2 - 4 } & Mixed language & 3 & 2.1 \\
\cline { 2 - 4 } & Others & & \\
\hline
\end{tabular}

Table 2 shows that out of 140 Kadazandusun respondents, only $43.6 \%$ have better grasp of their own mother tongues. The rest (56.6\%) were not able to speak the Kadazandusun language fluently. The same table also exhibits their usage of language at home. It appears that majority (55.7\%) of the respondents are using Malay language in their daily conversations at home, slightly more than $24 \%$ are using mixed languages and only $16 \%$ are using the Kadazandusun language.

Table 3:Stem-and-Leaf Plot for Language Proficiency and Use

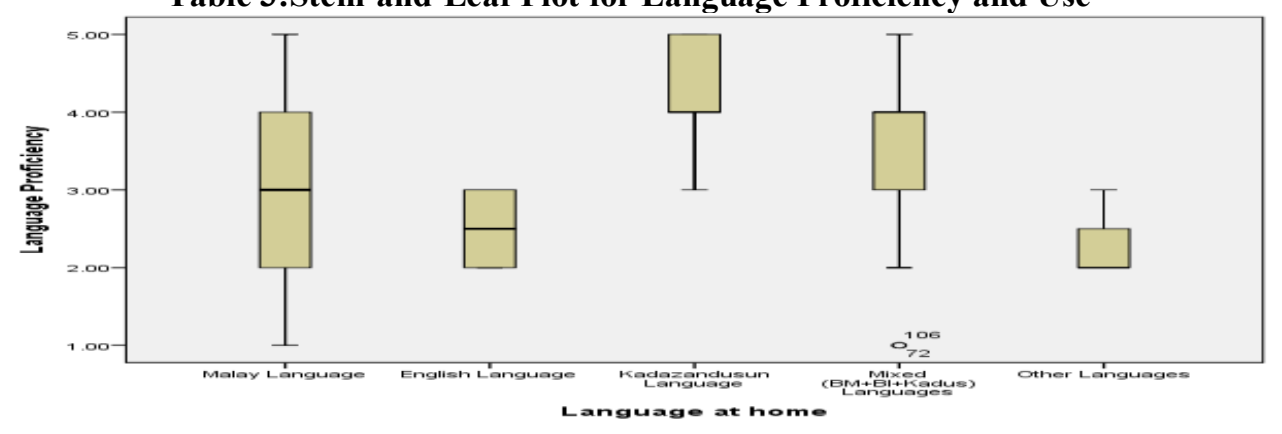

Even among the fluent speakers, only the very fluent speakers appear to use the Kadazandusun language at home, which is slightly more than $10 \%$. The fluent speakers $(32.9 \%)$ seem to prefer either Malay language or a mix of Malay, Kadazandusun and English languages. This data can be observed from the stemand-leaf plot in table 3 above.

\section{Media Interests and Reading Habits}

Previous literatures appear to suggest that youth's reading habits have been dwindling tremendously the last few decades, particularly after the development of media technologies. The media preference of youths has been going through a tremendous change from printed to electronic media. Such preferences are also occurring among the Kadazandusun youths in Sabah. The mean scores in Table 5 show that Kadazandusun youths appear to exhibit a higher interest in media communication technologies compared to print media. The interest on Internet obtained the highest mean score that is 4.4 followed by social media (4.38) and hand phones at 4.2. The interest in newspaper was only second (3.7) to the interest in books (3.8) in the print media category. The popularity of print media, including newspaper, appears to dwindle probably due to the development of electronic media and hand phones.

Table 4:Percentage of the Level of Interest on Media

\begin{tabular}{|l|c|c|c|c|c|c|c|c|}
\hline Level Of Interest & $\begin{array}{c}\text { News- } \\
\text { Paper }\end{array}$ & $\begin{array}{c}\text { Social } \\
\text { Media }\end{array}$ & Internet & Tv & Radio & Magazine & Book & $\begin{array}{c}\text { Hand- } \\
\text { Phone }\end{array}$ \\
\hline Very uninterested & 1.4 & 0 & 0 & 2.1 & 5.7 & 5.7 & 2.1 & 1.4 \\
\hline Uninterested & 2.1 & 0 & 0 & 2.9 & 5.7 & 5.7 & 2.9 & 2.1 \\
\hline Less interested & 35.0 & 6.4 & 5.7 & 4.3 & 22.9 & 27.1 & 24.3 & 11.4 \\
\hline Interested & 49.3 & 48.6 & 48.6 & 56.4 & 51.4 & 50.0 & 58.6 & 42.1 \\
\hline Very interested & 12.1 & 45.0 & 45.7 & 33.6 & 14.3 & 11.4 & 12.1 & 42.9 \\
\hline
\end{tabular}


Table 5:Media Interest Among Kadazandusun Youths

\begin{tabular}{|l|r|r|r|r|}
\hline & $\mathrm{N}$ & Mean & Std. Deviation & Std. Error Mean \\
\hline Newspaper & 140 & 3.6857 & .76887 & .06498 \\
Social Media & 140 & 4.3857 & .60675 & .05128 \\
Internet & 140 & 4.4000 & .59736 & .05049 \\
TV & 140 & 4.1714 & .81305 & .06872 \\
Radio & 140 & 3.6286 & .99164 & .08381 \\
Magazine & 140 & 3.5571 & .96910 & .08190 \\
Book & 140 & 3.7571 & .78540 & .06638 \\
Handphone & 140 & 4.2286 & .84260 & .07121 \\
\hline
\end{tabular}

These results appear to support the first hypothesis that is H1: Kadazandusun youths are no longer interested to read the newspaper. They seem to utilize most of their time with more interactive media forms. This outcome also supports the outcomes of research by Liu (2005) andPandian(2010). Youth glaring interests in technological based media such as social media is generated through their elements of interactivity and engagement. Alex Bruns (2008) uses the term "produsage" to describe the relationship between the users and various social media forms. Bruns (2008) further asserts that in social media environments, 'users' become active participants: creatingcontent, commenting and disliking/liking content, and forwarding links to content. Thiscontrasts with how information was utilized, created, and shared in Web 1.0, where usersshowed minimal interactivity and engagement (cited from Quan-Haase\& Young, 2014).

Table 6: Reasons for not Reading Newspaper

\begin{tabular}{|l|r|r|r|r|}
\hline \multicolumn{1}{|c|}{$\mathrm{N}$} & Mean & Std. Deviation & \multicolumn{1}{c|}{ Std. Error Mean } \\
\hline No newspaper in campus & 140 & 4.3357 & 4.41810 & .37340 \\
No time reading & 140 & 4.0714 & .86201 & .07285 \\
Newspaper not interesting & 140 & 3.5857 & 1.03177 & .08720 \\
Newspaper Vs. Internet & 140 & 3.6071 & 1.02274 & .08644 \\
Newspaper not relevant anymore & 140 & 2.8571 & 1.08337 & .09156 \\
\hline
\end{tabular}

The diminution of interest in newspaper reading was exacerbated by the non-availability of newspaper in the campus and time constraints. As a student they tend to spend most of their time doing their academic work. The respondents rated the non-availability of newspaper in campus and no time to read as the important reasons why they do not read newspaper as reflected from the obtained mean scores of 4.3 and 4.1 respectively in the Table 6.

\section{Kadazandusun Youths and the Kadazandusun Column}

There are no known studies that have been conducted to explore the interests of Kadazandusun readers on the Kadazandusun column in Sabah's local newspapers. This is the first attempt to investigate and understand the reception and interests of the Kadazandusun youths towards the Kadazandusun column. The study appearsto show that Kadazandusun youths prefer to read news in Malay language (mean score 4.5) and followed by news in English (4.1). News in Kadazandusun appeared to be the last choice (2.7). The results are demonstrated in Table 7. It seems that the level of proficiency is significantly correlated to the choice of newspaper they read. Table 8 demonstrates that only respondents with good proficiency of the Kadazandusun language appear to read the Kadazandusun news as shown through the obtained significant correlation level of .000.

Table 7: Choice of Newspaper

\begin{tabular}{|l|r|r|r|r|}
\hline & N & Mean & \multicolumn{1}{|c|}{ Std. Deviation } & \multicolumn{1}{c|}{ Std. Error Mean } \\
\hline BM News & 140 & 4.5143 & .61732 & .05217 \\
BI News & 140 & 4.0643 & 3.48731 & .29473 \\
ChineseNews & 140 & 1.3786 & .81768 & .06911 \\
KadazandusunNews & 140 & 2.6643 & 1.19116 & .10067 \\
TamilNews & 140 & 1.1000 & .42069 & .03555 \\
\hline
\end{tabular}

Table 8: Correlation between Language Proficiency and Choice of Newspaper

\begin{tabular}{|ll|r|r|}
\hline & & KadazandusunNews & Language Proficiency \\
\hline & Pearson Correlation & 1 & $.620^{* *}$ \\
& Sig. (2-tailed) & & .000 \\
KadazandusunNews & Sum of Squares and Cross-products & 197.221 & 1.419 \\
& Covariance & 140 & 108.093 \\
& $\mathrm{~N}$ & $.620^{* *}$ & .778 \\
Language Proficiency & Pearson Correlation & 140 \\
\end{tabular}




\begin{tabular}{|l|r|r|} 
Sig. (2-tailed) & .000 \\
Sum of Squares and Cross-products & 108.093 & .778 \\
Covariance & 140 & 154.136 \\
$\mathrm{~N}$ & 1.109 \\
140 \\
\hline$*$. Correlation is significant at the 0.01 level (2-tailed).
\end{tabular}

The main question in this study is why Kadazandusun youths appear unmotivated to read news from the Kadazandusun column? According to the Uses and Gratification Theory, audiences chose certain media forms and/or contents because they are able to satisfy their needs - a notion that supports the idea of active audience. The outcomes that have been presented above seem to suggest that Kadazandusun youths were uninterested to choose the Kadazandusun column. This requires further examination from the lenses of the U\&G theory.

Table 9: Motivations to Use Media

\begin{tabular}{|l|r|r|r|r|}
\hline & $\mathrm{N}$ & Mean & Std. Deviation & \multicolumn{1}{c|}{ Std. Error Mean } \\
\hline information & 140 & 14.8643 & 8.32022 & .70319 \\
Identity & 140 & 12.4571 & 3.99364 & .33752 \\
Entertainment & 140 & 12.5214 & 2.06154 & .17423 \\
Personal Relationship & 140 & 12.2857 & 2.21274 & .18701 \\
\hline
\end{tabular}

According to the U\&G theory (McQuail et al., 1972), audiences choose certain media forms because they provide information (surveillance), personal identity, diversion (entertainment $\&$ escapism) and personal relationship. Table 9 shows that the Kadazandusun youths would choose or be motivated to use media that provide more information, which obtained a mean score of 14.86 . The results show that the main reason for the Kadazandusun students to choose a media was because of information values. Their choice is justifiable because they are students in a higher learning institution who need to constantly seek information for their studies. News that is able to enhance their Entertainment came second with a mean score of 12.52. The elements of entertainment have always appeal youngsters particularly when comes to selecting what to read. This result appears to support the study outcome of Eighmey and McCord (1995).Personal identity came third with a mean score of 12.45 followed by personal relationship with a mean score of 12.28 .

Table 10: Gratifications Sought from the Kadazandusun Columns

\begin{tabular}{|l|r|r|r|r|}
\hline & $\mathrm{N}$ & Mean & Std. Deviation & Std. Error Mean \\
\hline GratifyInfomation & 140 & 11.3000 & 1.98809 & .16802 \\
GratifyIdentity & 140 & 12.3571 & 4.68285 & .39577 \\
GratifyEntertainment & 140 & 11.0214 & 3.37888 & .28557 \\
GratifyRelationship & 140 & 10.2714 & .23159 \\
\hline
\end{tabular}

The proceeding section assesses how far their needs have been fulfilled or gratified? The results in the Table 10 revealed the respondents gratifications on the Kadazandusun columns. It appears that Kadazandusun youths are satisfied with the contents of the Kadazandusun columns that promote and enhance Kadazandusun identity through the usage of the Kadazandusun language. However, they felt that the Kadazandusun language used in the columns is difficult for them to comprehend due to their poor command of the language. Poor command of the language is one of the main reasons that contribute to the choice of newspaper among the Kadazandusun youths. Table 11 shows that out of the 140 respondents, 110 or $78.6 \%$ agreed that they do not read the news in the Kadazandusun columns because of language proficiency.

Table 11: Justifications of Choice

\begin{tabular}{|l|c|c|c|c|c|c|}
\hline \multirow{2}{*}{} & \multicolumn{2}{|c|}{$\begin{array}{c}\text { Do not understand } \\
\text { Kadazandusun }\end{array}$} & \multicolumn{2}{c|}{ Can get from BM \& BI sections } & \multicolumn{2}{c|}{ Info not interesting } \\
\cline { 2 - 7 } & Frequency & Percentage & Frequency & Percentage & Frequency & Percentage \\
\hline Agreement & 110 & 78.6 & 136 & 97.1 & 126 & 90.0 \\
\hline
\end{tabular}

Besides that Table 11 also demonstrates that the availability of the Kadazandusun column's contents in the Malay and English versionsis another significant justification to their choice of newspaper. It means that all the news presented in the Kadazandusun columns is available in the Malay or English columns. Therefore, there is no need for them to read news from the Kadazandusun columns. Kadazandusun youths also seemed dissatisfied with the columns with regard to information and entertainment values. They felt that the Kadazandusun columns failed to provide them with interesting news and information that attract their needs as youths. Presently, most of the contents in the Kadazandusun columns are catered for older generations such as news on politics, which to them are 'heavy news'. Respondents would like to see more 'light' and entertaining 
contents such as poetry, short story, crosswords, and other brain teasers. This result is congruent with the result obtained from the studies conducted by the World Wide Web as cited from Ruggiero (2000) and Barnhurst and Wartella (1991).

In general, the contents of the Kadazandusun columns seem to fall short to gratify the needs of the Kadazandusun readers especially on the aspects of entertainment and information values. Therefore, these results support the $2^{\text {nd }}$ and $3^{\text {rd }}$ hypothesis of this study that are: $\mathrm{H} 2$ : Kadazandusun youths are not interested to read news from the Kadazandusun columns; and H3: Kadazandusun youths do not read news from the Kadazandusun columns because they do not provide gratification to young readers.

\section{Suggestions for Improvement}

This study also presents some of the suggestions proposed by the respondents to improve the Kadazandusun columns. Most of the suggestions were related to the contents and level of language used in the news. Below lists the suggestions proposed by the respondents.

1. Include more 'light' and interesting news instead of 'heavy' news such as political and economic news. Increase news that promotes tradition and cultural heritages of Borneo, particularly from the Kadazandusun people such as Kadazandusun poetry, quizzes, song lyrics, quotes, native laws and short folklore and funny stories as well as prices of goods and commodities.

2. Introduce an educational section where readers are able to learn the Kadazandusun language such as crosswords, simple tests, word games and brain teasers.

3. Provide a glossary section in the columns to explain difficult words or phrases in Malay and/or English languages.

4. Put more cartoons and comics.

5. Introduce a section about learning the Kadazandusun language.

\section{Conclusion}

It appears that the Kadazandusun youths are no longer interested to read newspaper. They were more inclined towards electronic media such as Internet and social media and particularly hand phones. They spent about 30 hours a week on the Internet especially on Facebook and more than 30 hours a week on their hand phones, which is exceedingly higher than the time spent on physical activities. Such paucity of interest on newspaper was exacerbated by the absence of attractiveness and responsiveness of the Kadazandusun columns towards the needs of younger Kadazandusun readers. Therefore, Kadazandusun youths were seldom, if not rare, to read news from the Kadazandusun columns. To increase their interests, the Kadazandusun columns need to be transformed vis-à-vis to 'lighten' their news and put more elements of entertainment to captivate the interests and cater the needs of young Kadazandusun people.

\section{References}

[1]. AnasAlamFaizli (2012). Changing Nation's Fate Through Reading. Downloaded from http://freemalaysiatoday.com.

[2]. ArkibNegeri Sabah (1994).Akhbar: PembukaMindaMasyarakat. Kota Kinabalu: ArkibNegeri Sabah.

[3]. Bantz, C. R. (1982). Exploring uses and gratifications: A comparison of reported uses of television andreported uses of favorite program type. Communication Research, 9, 352-379.

[4]. Barnhurst, K.G. and Wartella, E. (1991). Newspapers and citizenship: young adults' subjective experience of newspapers. Critical Studies in Mass Communication, vol. 8, issue 2, p. 195-209.

[5]. Bentley, C. H. (2000). Make My Day: Ritual, Dependency andthe Habit of Newspaper Reading. Downloaded from http://web.missouri.edu/.

[6]. Blumler, J. G. (1979). The role of theory in uses and gratifications studies.Communication Research, 6,9-36.

[7]. Chandler, D. and Munday, R. (2011).Dictionary of Media and Communication. Oxford: Oxford University Press.

[8]. Ferguson, D. A., \&Perse, E. M. (2000). The World Wide Web as a functional alternative to television.Journal of Broadcasting \& Electronic Media, 44(2), 155-174.

[9]. Frank Small and Associates, (1996).Reading Profile of Malaysians 1996. Kuala Lumpur: Perpustakaan Negara Malaysia. Ha, L. and James, E.L. (1998). Interactivity re-examined: A baseline analysis of early business Web sites. Journal of Broadcasting and Electronic Media, 42, 457-474.

[10]. Katz, E., Blumler, J., \&Gurevitch, M. (1974).Utilization of mass communication by the individual. In J.Blumler\& E. Katz (Eds.), The uses of mass communication: Current perspectives on gratifications research (pp. 19-34). Beverly Hills, CA: Sage

[11]. Kaur, S. \&Thiyagarajah, R. (1999).The English Reading Habits of ELLS Students in University Science Malaysia.Proceedings of the Sixth International Literacy and Education Research Network Conference on Learning, Malaysia.

Liu, Z. (2005). Reading behavior in the digital environment: Changes in reading behavior over the past 10 years.Journal of Documentation, 61 (6), 700-712.

[12]. McQuail, D., J. Blumler\& R. Brown (1972): 'The television audience: a revised perspective' in D. McQuail (ed.): Sociology of Mass Communication. London: Longman.

[13]. McQuail, D. and Windhal, S. (1981). Communication models for the Study of Mass Communications. London \& New York: Longman.

[14]. Morris, M., \&Ogan, C. (1996). The Internet as mass medium.Journal of Communications, 46(1),39-50.

[15]. Nor ShahrizaAbd.Rahim (2006). Reading Habits and Attitudes in Malaysia: Analysis of Gender and Academic Programme Difference. KekalAbadi, 25 (1/2). Downloaded from http://www.keka-abadi.um.edu.my. 
[16]. Nor Shahriza A. K., \& Amelia, H. (2007). Reading habits and attitude in the digital age: Analysis of gender and academic program differences in Malaysia. The Electronic Library, 25 (3), 285-298.

[17]. Ostman, R. E., \& Jeffers, D. W. (1980, June). The relationship of life-stage to motives for using television and the perceived reality of TV. Paper presented at the International Communication Association convention, Acapulco, Mexico

[18]. O'Sullivan, T., Hartley, J., Montgomery, M. and Fiske, J. (1994).Key Concepts in Communication and Cultural Studies $\left(2^{\text {nd }}\right.$ edition). London and New York: Routledge.

[19]. Palmgreen, P., \& Rayburn, J. D., II. (1979). Uses and gratifications and exposure to public television.Communication Research, 6 , 155-180.

[20]. Pandian, A. (1997).Literacy in Postcolonial Malaysia.Journal of Adolescent \& Adult Literacy, 440 (5), 402-405.

[21]. Pandian, A. (2000).A study on readership behavior among multi-ethnic, multi-lingual Malaysian students. Paper presented at the 7th International Literacy and Education Research Network (LERN) Conference on Learning, RMIT University, Melbourne. Quan-Haase, A. and Young, A.L. (2014).TheUsesandGratifications(U\&G)ApproachasaLensforStudyingSocialMediaPractice. International Handbook of Media and Mass Communication Theory.Downloaded from http://www.academia.edu.

[22]. Rubin, A. M. (1983). Television uses and gratifications: The interactions of viewing patterns and motivations. Journal of Broadcasting, 27, 37-51.

[23]. Ruggiero, T. E (2000). Uses and Gratifications Theory in the $21^{\text {st }}$ Century. Mass Communication and Society, 3(1), 3-37.

[24]. Sansalu, D. (2008). Kadazandusun Di Sabah: Pendidikandan Proses Pemodenan 1881-1967. Kuala Lumpur: Dewan Bahasa danPustaka.

[25]. SKMM (2012). Hand Phone Users Survey 2012: Statistical Brief Number Fourteen. Downloaded from www.skmm.gov.my/skmmgovmy/media/General/pdf/130717 HPUS2012.

[26]. pdf on 17 October 2013.

[27]. SubashiniAnnamalai and BalakrishnanMuniandy (2012).Reading Habit and Attitude among Malaysian Polytechnic Students.International Online Journal of Education Science, 5 (1), 32-41. 